\title{
A Comparative Study of Agnikarma \& Ajmodadi Vati in the Management of Ghridhrasi w.s.r.to Sciatica
}

\author{
Research Article
}

\author{
Anant Kumar V Shekokar ${ }^{1 *}$, Kanchan M.Borkar ${ }^{2}$ \\ 1. Reader \& HOD, 2. Lecturer, \\ Department of Shalya Tantra, Ayurved College Rahuri
}

\begin{abstract}
The disease Ghridhrasi is characterized by ruk in the kati region which will be radiating towards lower limb with cardinal symptoms like sakthankshepannigruhat (S.L.R test). The present study was taken up with the objective of evaluating the efficacy of Agnikarma, Ajmodadi Vati \& combination therapy. 56 patients of Gridhrasi were treated in three groups. Group A were treated with Agnikarma and consisted of 22 patients, Group B with Ajmodadi Vati and consisted of 18 patients and Group C with Combined therapy and included 16 patients. The data was collected \& observations were made before and after the treatment. The results obtained were subjected for statistical analysis \& conclusions were drawn. The results showed that there was significant reduction in the symptomatic parameters in combined therapy when compared to the other two groups.
\end{abstract}

Key words - Gridharsi, Agnikarma, Ajmodadi Vati, Sciatic nerve, S.L.R.test

\section{Introduction}

$80 \%$ of population in modern industrial society experience back pain at sometime during their life, fortunately in some of these subsides within a month. But unfortunately as many as $70 \%$ of these pains recurs and may get converted diseases like spondylosis, intervertebral disc prolapse (IVDP) etc. Gridhrasi (Sciatica) is one of the most common disorders of the back where the compression of the sciatic nerve causes pain in the back and radiates to the posterior aspect of the lower limbs. It causes impairment of the daily activities also (1).

The disease Gridhrasi is

*Corresponding Author:

Anant kumar V Shekokar,

HOD and Reader,

Department of Shalya Tantra,

Ayurved college, Rahuri, 413706.

Maharashtra, India.

Email-dranantkumarshekokar@gmail.com characterized by ruk (Severe pain) from Kati (Lumbar region) pradesha which will be radiating towards Padanguli (Foot) with cardinal symptoms like sakthankshepannigruhat (Straight Leg Raising test) (2). Medically the disease requires anti-inflammatory treatment to reduce the pain. If the compression of the nerve causes disability, then the surgical correction procedures can be adopted for relieving the compression.

Ayurveda mentions Gridhrasi as a disease where the patient's gait will be similar to the gait of the Gridhra (Eagle). This change in the gait is because of the pain in the back and the lower limbs and the patient starts limping towards the affected side. Various medical and parasurgical methods are indicated for the management of the disease. One of the surgical methods mentioned is the Agnikarma (3).

Hence the present study is taken up to know the efficacy of the Agnikarma in the management of the disease Gridhrasi 
in comparison with the medical management with Ajmodadi Vati. The combined efficacy of the two therapies is also studied in the study as follows.

Aims and Objectives:

- To study the role of Agnikarma and Ajmodadi Vati in the management of Gridhrasi.

- To study the comparative efficacy of both the therapeutic procedures and also the combined efficacy.

- To establish the probable mode of action of Agnikarma and Ajmodadi Vati in the management of Gridhrasi.

\section{Materials and methods:}

For the present study, two therapies have been selected.
1) Agnikarma
2) Ajmodadi Vati

\section{Materials for agnimarka:}

The Shalaka, Prota (gauze), Pichu (cotton), Gas stove, match box, Triphala Kashaya, Swab holding forceps, Kumari Swarasa, Yashtimadhu churna.

\section{Composition of Ajmodadi Vati} (Chakradatta 25/51-55) (4).

Each Vati of $500 \mathrm{mg}$ Contains :

$\begin{array}{ll}\text { Ajmoda } & \text { 1 part } \\ \text { Vidanga } & \text { 1 part } \\ \text { Saindhava Lavana } & \text { 1 part } \\ \text { Pippali } & \text { 1 part } \\ \text { Devadaru } & \text { 1 part } \\ \text { Vrudhadaru } & \text { 10 part } \\ \text { Chitraka } & \text { 1 part } \\ \text { Pippali Mula } & \text { 1 part } \\ \text { Satahva } & \text { 1 part } \\ \text { Maricha } & \text { 1 part } \\ \text { Haritaki } & \text { 5 part } \\ \text { Sunthi } & \text { 10 part } \\ \text { Guda } & \text { Equal part of } \\ & \text { the rest of the } \\ & \text { drug }\end{array}$

Dose : 2 (500 mg each) vati three time in a day with lukewarm water.
All above mentioned drugs, Charaka have been explained in Shulaprashamanam (analgesic) gana (5) and Sushruta has explained in Pipalyadi gana, which acts as a Deepana, Vatakaphahara, Aruchi, Amarasa pachana, Gulma and Shoolaghataka (6).

\section{Clinical Contrive:}

The study is a comparative clinical study. 56 patients attending the OPD and IPD of the Department of Shalya tantra of Ayurved College, Rahuri were selected irrespective of their age, sex, religion etc were selected for the study and the written consent was taken from each patient.. A detailed research case-sheet was prepared to obtain the proper diagnosis of the disease and assess the parameters of the study.

\section{Criteria of Selection of Patient}

Patients were diagnosed mainly on the basis of signs and symptoms as mentioned in the texts of Ayurveda and modern medical signs like Ruka, Toda, Stambha, Spandana, Sakthanakshepananigrahaniyat, S.L.R. test (Lasegue sign), sitting test in affected leg for diagnosis as well as prognosis of the treatment.

\section{Criteria for inclusion:}

- Patients diagnosed as suffering from the Grudrasi disease based on the symptoms mentioned in the Ayurvedic Texts.

- Patients willing to undergo Agnikarma.

- Patients having good tolerance to the procedures.

\section{Criteria for the Exclusion}

The patient suffering with -

- Carcinoma of lumbo-sacral plexus

- Carcinoma of caudaequina

- Pregnancy

- Tuberculosis

- Uncontrolled Diabetes mellitus etc. 
- Chronic diseases etc were excluded from the present study.

\section{Management}

After the diagnosis of the disease, 56 patients were selected and randomly categorized into three groups as given below.

Group A: In this group, the treatment procedure adopted is Agnikarma.

Group B: In this group, Ajmodadi Vati was administered $3 \mathrm{gm} /$ day with lukewarm water for 30 days.

Group C: In this group, both the therapies were adopted.

\section{Procedure of Agnikarma(3):}

Agnikarma is done to the selected patients in two sittings. In the $1^{\text {st }}$ sitting agnimarka is done in the shape of a Bindu (drop) type at Antara Kandara Gulpha Madhya (In the middle of the posterior aspect of the knee joint). The $2^{\text {nd }}$ sitting is done after 15 days at the same site of the $1^{\text {st }}$ sitting of Agnikarma.

The entire procedure consists three parts.

- Purva karma (Pre-operative procedure)

- Pradhana karma (Operative procedure)

- Paschat karma (Post-operative procedure)

\section{Purva Karma (Pre-operative Procedure):}

Prior to the procedure the patient's are prepared for the procedure. They were advised to consume Snigdha, Picchila and light diet on the day before the Agnikarma chikitsa. Written consent of the patients was taken.

\section{Pradhana Karma (Operative Procedure):}

The patients were made to rest comfortably on the operation table and the diseased side of the limb is washed with Triphala kashaya or Savlon to avoid any infection. The Loha dhatu Shalaka was heated to red hot on fire. On the affected leg of the patient at the site of 4 angula (inches) above of Gulpha sandhi (knee joint) on the posterior side Agnikarma is done with the heated shalaka to form 5 30 bindu (droplet) sized (bindu dahana vishesha) burns in a linear fashion (Vilekha), till the Samyaka dagdha vrana were produced.

\section{Paschat Karma (Post Operative Procedure):}

After producing Samyaka Dagdha Vrana, the Kumari Swarasa was applied on samyaka dagdha vrana to get relief from burning sensation. After wiping the Kumari Swarasa, Avachurnan (dusting) of Yashtimadhu churna was done on Samyaka Dagdha Vrana and patient was advised for local application of Haridra powder with mixed coconut oil from the second day of the procedure to promote healing and act as disinfectant. Pathyapathya was advised as per Sushrutacharya's Vrana Rogadhikara until healing of Samyaka Dagdha Vrana.

\section{Criteria for Assessment:}

The improvement in the patient was assessed mainly on the basis of relief in the cardinal signs and symptoms of the disease.

\section{Criteria for Assessing the Total Effect:}

The overall improvement shown by the patients in sign and symptoms is assessed as follows:

$\begin{array}{lll}\text { Cured } & -100 \% \text { relief of } \\ & \text { presenting complaint } \\ \text { Marked } & -\begin{array}{l}\text { More than 50\% relief in } \\ \text { the complaints of the } \\ \text { improvement } \\ \text { patient }\end{array} \\ \text { Improvement }- & \begin{array}{l}25-50 \% \text { relief in the } \\ \text { complaints of the } \\ \text { patient }\end{array} \\ \text { Unchanged }- & \begin{array}{l}\text { Upto } 25 \% \text { relief in the } \\ \text { complaints of the } \\ \text { patient }\end{array}\end{array}$


Observation \& Result

The following tables mentioned indicate the observations made during the study

Table 1: Occupation wise distribution patients of Gridhrasi

\begin{tabular}{|l|l|l|l|l|l|}
\hline \multirow{2}{*}{ Occupation } & \multicolumn{3}{l|}{ No. of Patients } & \multirow{2}{*}{ Total } & \multirow{2}{*}{$\%$} \\
\cline { 2 - 6 } & Group A & Group B & Group C & & 14.28 \\
\hline Business & 4 & 2 & 2 & 8 & 14.28 \\
\hline Service & 2 & 3 & 3 & 8 & 32.14 \\
\hline Labor & 7 & 7 & 4 & 18 & 35.71 \\
\hline Housewife & 9 & 5 & 6 & 20 & 3.57 \\
\hline Others & 00 & 1 & 1 & 2 & \\
\hline
\end{tabular}

Table 2: Chronicity wise distribution patients of Gridhrasi

\begin{tabular}{|l|l|l|l|l|l|}
\hline \multirow{2}{*}{ Chronicity } & \multicolumn{2}{|l|}{ No. of Patients } & \multirow{2}{*}{ Total } & \multirow{2}{*}{$\%$} \\
\cline { 2 - 5 } & Group A & Group B & Group C & & 51.78 \\
\hline $0-1$ year & 10 & 9 & 10 & 29 & 17.85 \\
\hline $1-2$ years & 6 & 1 & 3 & 10 & 30.35 \\
\hline$>2$ years & 6 & 8 & 3 & 17 & \\
\hline
\end{tabular}

Table 3: Straight Leg Raising (SLR) test wise distribution patients of Gridhrasi

\begin{tabular}{|l|l|l|l|l|l|}
\hline \multirow{2}{*}{ S.L.R. } & No. of Patients & \multirow{2}{*}{ Total } & \multirow{2}{*}{$\%$} \\
\cline { 2 - 5 } & Group A & Group B & Group C & & 41.07 \\
\hline Right & 7 & 10 & 6 & 23 & 53.57 \\
\hline Left & 12 & 8 & 10 & 30 & 5.35 \\
\hline Both & 3 & 00 & 00 & 3 & \\
\hline
\end{tabular}

Table 4 : Lasegue's sign wise distribution patients of Gridhrasi

\begin{tabular}{|l|l|l|l|l|l|}
\hline \multirow{2}{*}{ Lasegue Sign } & \multicolumn{2}{|l|}{ No. of Patients } & \multirow{2}{*}{ Total } & \multirow{2}{*}{$\%$} \\
\cline { 2 - 6 } & Group A & Group B & Group C & & 50.00 \\
\hline Right & 12 & 9 & 7 & 28 & 50.00 \\
\hline Left & 10 & 9 & 9 & 28 & 00 \\
\hline Both & 00 & 00 & 00 & 00 & \\
\hline
\end{tabular}

Table 5 : Popletial compression wise distribution of 56 patients of Gridhrasi

\begin{tabular}{|l|l|l|l|l|l|}
\hline \multirow{2}{*}{$\begin{array}{l}\text { Popletial } \\
\text { compression }\end{array}$} & \multicolumn{2}{|l|}{ No. of Patients } & \multirow{2}{*}{ Total } & \multirow{2}{*}{} \\
\cline { 2 - 6 } & Group A & Group B & Group C & & 78.57 \\
\hline Positive & 17 & 13 & 14 & 44 & 21.42 \\
\hline Negative & 5 & 5 & 2 & 12 & \\
\hline
\end{tabular}

Table 6 : Tenderness wise distribution of patients of Gridhrasi

\begin{tabular}{|l|l|l|l|l|l|}
\hline \multirow{2}{*}{ Tenderness } & \multicolumn{2}{l|}{ No. of Patients } & \multirow{2}{*}{ Total } & \multirow{2}{*}{ \% } \\
\cline { 2 - 6 } & Group A & Group B & Group C & & 53.57 \\
\hline Lumbar & 13 & 7 & 10 & 30 & 16.07 \\
\hline Gluteal & 4 & 2 & 3 & 9 & 8.92 \\
\hline Thigh & 2 & 1 & 2 & 5 & 44.64 \\
\hline Calf & 12 & 7 & 6 & 25 & \\
\hline
\end{tabular}


Table 7 : Length of leg (Scoliosis) wise distribution of patients of Gridhrasi

\begin{tabular}{|l|l|l|l|l|l|}
\hline \multirow{2}{*}{ Length of Leg } & \multicolumn{2}{|l|}{ No. of Patients } & \multirow{2}{*}{ Total } & \multirow{2}{*}{} \\
\cline { 2 - 6 } & Group A & Group B & Group C & & 76.78 \\
\hline Normal & 17 & 13 & 13 & 43 & 23.21 \\
\hline Shorting & 5 & 5 & 3 & 13 & \\
\hline
\end{tabular}

Table 8 : Neurological findings wise distribution of patients of Gridhrasi

\begin{tabular}{|l|l|l|l|l|l|}
\hline \multirow{2}{*}{$\begin{array}{l}\text { Neurological } \\
\text { Findings }\end{array}$} & \multicolumn{2}{|l|}{ No. of Patients } & \multirow{2}{*}{ Total } & \multirow{2}{*}{$\%$} \\
\cline { 2 - 5 } & Group A & Group B & Group C & & 10.71 \\
\hline Hyperasthesia & 4 & 1 & 1 & 6 & 50 \\
\hline Hypoasthesia & 9 & 11 & 8 & 28 & 19.64 \\
\hline Loss of sensation & 5 & 3 & 4 & 12 & \\
\hline
\end{tabular}

Table 9 : Muscles wasting wise distribution of patients of Gridhrasi

\begin{tabular}{|l|l|l|l|l|l|}
\hline \multirow{2}{*}{ Muscle Wasting } & \multicolumn{2}{|l|}{ No. of Patients } & \multirow{2}{*}{ Total } & \multirow{2}{*}{ \% } \\
\cline { 2 - 6 } & Group A & Group B & Group C & & 10.71 \\
\hline Present & 2 & 1 & 3 & 6 & 89.28 \\
\hline Absent & 20 & 17 & 13 & 50 & \\
\hline
\end{tabular}

Table 10 : Effect of therapy on symptoms of Gridhrasi in Group A : Agnikarma

\begin{tabular}{|c|c|c|c|c|c|c|c|}
\hline \multirow{2}{*}{$\begin{array}{l}\text { Cardinal } \\
\text { symptoms }\end{array}$} & \multicolumn{2}{|c|}{ Means score } & \multirow{2}{*}{ \pm SD } & \multirow{2}{*}{$\pm \mathrm{SE}$} & \multirow{2}{*}{ ' $\mathbf{t}$ ' } & \multirow{2}{*}{$\mathbf{P}$} & \multirow{2}{*}{$\%$} \\
\hline & B.T. & A.T. & & & & & \\
\hline Ruka & 2.52 & 1.11 & 0.60 & 0.14 & 10.07 & $<0.001$ & 50 \\
\hline Toda & 2.45 & 0.90 & 0.68 & 0.20 & 7.7 & $<0.001$ & 63 \\
\hline Stambha & 2.28 & 0.57 & 0.72 & 0.19 & 9 & $<0.001$ & 75 \\
\hline Spandana & 1.75 & 0.5 & 0.49 & 0.24 & 5.20 & $<0.02$ & 71 \\
\hline Aruchi & 2.2 & 1 & 0.74 & 0.33 & 3.63 & $<0.05$ & 54 \\
\hline Tandra & $\mathrm{n}=0$ & - & - & - & - & - & - \\
\hline Gaurava & 2.6 & 1 & 0.54 & 0.25 & 6.66 & $<0.01$ & 61 \\
\hline S.L.R. Test & 2.11 & O.76 & 0.60 & 014 & 9.64 & $<0.01$ & 63 \\
\hline Sciolosis & 2 & 1.25 & 0.49 & 0.24 & 3.12 & $<0.10$ & 37 \\
\hline Shotha & 1 & 0 & - & - & - & - & 100 \\
\hline
\end{tabular}

Table 11: Effect of therapy on symptoms of Gridhrasi in Group B: Ajmodadi Vati

\begin{tabular}{|c|c|c|c|c|c|c|c|}
\hline \multirow{2}{*}{$\begin{array}{l}\text { Cardinal } \\
\text { symptoms }\end{array}$} & \multicolumn{2}{|c|}{ Means score } & \multirow{2}{*}{ \pm SD } & \multirow{2}{*}{$\pm \mathrm{SE}$} & \multirow{2}{*}{ ' $\mathbf{t}$ ' } & \multirow{2}{*}{$\mathbf{P}$} & \multirow{2}{*}{$\%$} \\
\hline & B.T. & A.T. & & & & & \\
\hline Ruka & 1.53 & 1.92 & 0.50 & 0.13 & 4.69 & $<0.001$ & 24 \\
\hline Toda & 2 & 1 & 0.56 & 0.17 & 5.29 & $<0.001$ & 50 \\
\hline Stambha & 2.22 & 1.55 & 0.49 & 0.17 & 3.88 & $<0.01$ & 30 \\
\hline Spandana & 1.57 & 0.42 & 0.53 & 0.20 & 5.7 & $<0.01$ & 73 \\
\hline Aruchi & 2 & 0.25 & 0.70 & 0.24 & 7.29 & $<0.001$ & 87 \\
\hline Tandra & 1 & 0.5 & - & - & - & - & 25 \\
\hline Gaurava & 2 & 0.81 & 0.60 & 0.18 & 6.55 & $<0.001$ & 59 \\
\hline S.L.R. Test & 2.30 & 1.69 & 0.5 & 0.13 & 4.69 & $<0.001$ & 26 \\
\hline Sciolosis & 2 & 1.8 & 0.44 & 0.19 & 1.05 & $>0.10$ & 10 \\
\hline Shotha & 1 & 1 & - & - & - & - & 0 \\
\hline
\end{tabular}


Table 12: Effect of therapy on symptoms of Gridhrasi in Group C : Combined Therapy

\begin{tabular}{|c|c|c|c|c|c|c|c|}
\hline \multirow{2}{*}{$\begin{array}{l}\text { Cardinal } \\
\text { symptoms }\end{array}$} & \multicolumn{2}{|c|}{ Means score } & \multirow{2}{*}{ \pm SD } & \multirow{2}{*}{$\pm \mathrm{SE}$} & \multirow{2}{*}{ ' $\mathbf{t}$ ' } & \multirow{2}{*}{$\mathbf{P}$} & \multirow{2}{*}{$\%$} \\
\hline & B.T. & A.T. & & & & & \\
\hline Ruka & 2.33 & 0.83 & 0.52 & 0.15 & 10 & $<0.001$ & 65 \\
\hline Toda & 1.77 & 0.33 & 0.72 & 0.24 & 6 & $<0.001$ & 81 \\
\hline Stambha & 2.08 & 0.41 & 0.77 & 0.22 & 7.18 & $<0.001$ & 80 \\
\hline Spandana & 3.5 & 1.5 & - & - & - & - & 57 \\
\hline Aruchi & 2.33 & 0.16 & 0.74 & 0.30 & 7.2 & $<0.001$ & 93 \\
\hline Tandra & 1 & 0 & - & - & - & - & 100 \\
\hline Gaurava & 2.33 & 0.66 & 0.81 & 0.33 & 5.03 & $<0.01$ & 71 \\
\hline S.L.R. Test & 2.41 & 1.08 & 0.65 & 0.18 & 7.38 & $<0.001$ & 51 \\
\hline Sciolosis & 2 & 0.6 & 0.77 & 0.34 & 4.11 & $<0.02$ & 70 \\
\hline Shotha & 1 & 1 & 0 & - & - & - & 0 \\
\hline
\end{tabular}

Table 13: Chronicity wise effect of therapy

\begin{tabular}{|c|c|c|c|c|c|c|c|c|c|c|c|c|}
\hline \multirow[t]{3}{*}{ Chrocnicity } & \multicolumn{3}{|c|}{ Cured } & \multicolumn{3}{|c|}{$\begin{array}{l}\text { Markedly } \\
\text { improved }\end{array}$} & \multicolumn{3}{|c|}{ Improved } & \multicolumn{3}{|c|}{ Unimproved } \\
\hline & \multicolumn{3}{|c|}{ Group } & \multicolumn{3}{|c|}{ Group } & \multicolumn{3}{|c|}{ Group } & \multicolumn{3}{|c|}{ Group } \\
\hline & $\mathrm{A}$ & $\mathrm{B}$ & $\mathrm{C}$ & $\mathrm{A}$ & B & $\mathrm{C}$ & $\mathrm{A}$ & B & $\mathrm{C}$ & $\mathrm{A}$ & $\mathrm{B}$ & $\mathrm{C}$ \\
\hline $0-1$ year & 0 & 0 & 0 & 4 & 1 & 9 & 4 & 5 & 0 & 0 & 0 & 0 \\
\hline $1-2$ year & 0 & 0 & 0 & 5 & 0 & 0 & 1 & 1 & 1 & 0 & 0 & 0 \\
\hline$>2$ year & 0 & 0 & 0 & 2 & 0 & 2 & 1 & 6 & 0 & 0 & 0 & 0 \\
\hline
\end{tabular}

Table 14: Comparative study of overall effect of therapy in all groups

\begin{tabular}{|l|l|l|l|}
\hline Effect & Group A & Group B & Group C \\
\hline Cured & $0 \%$ & $0 \%$ & $0 \%$ \\
\hline Markedly improved & $64.70 \%$ & $7.69 \%$ & $91.66 \%$ \\
\hline Improved & $35.30 \%$ & $92.30 \%$ & $8.33 \%$ \\
\hline Unimproved & $0 \%$ & $0 \%$ & $0 \%$ \\
\hline
\end{tabular}

Table 15: Comparative study of Results in all groups

\begin{tabular}{|l|l|l|l|}
\hline Cardinal Symptoms & Group A & Group B & Group C \\
\hline Ruka & $50.00 \%$ & $24.00 \%$ & $65 \%$ \\
\hline Toda & $63.00 \%$ & $57.00 \%$ & $81.00 \%$ \\
\hline Stambha & $75.00 \%$ & $30.00 \%$ & $80.00 \%$ \\
\hline Sapandana & $71.00 \%$ & $73.00 \%$ & $57.00 \%$ \\
\hline Aruchi & $54.00 \%$ & $87.00 \%$ & $93.00 \%$ \\
\hline Tandra & - & $25.00 \%$ & $100 \%$ \\
\hline Gaurava & $61.00 \%$ & $59.00 \%$ & $71.00 \%$ \\
\hline S.L.R. Test & $63.00 \%$ & $26.00 \%$ & $55.00 \%$ \\
\hline Scilosis & $37.00 \%$ & $10.00 \%$ & $70.00 \%$ \\
\hline Shotha & $100 \%$ & - & $100 \%$ \\
\hline
\end{tabular}

\section{Discussion:}

Gridhrasi (Sciatica) is one of the commonest causes of the low back ache.
Treatment of the disease is a challenge to the medical profession. It may also lead to 
severe disability to walk and do the normal routine works.

Gridhrasi comes under Nanatmaja vata vyadhi vikara, according to Ayurveda (7), that is it is caused by the vitiation of the vata, which is the prime factor for the control of the neurological tissues. Ayuvredic texts have mentioned the different types of procedures like Agnikarma etc for the treatment of the disease. Based on the same principle the present study has been designed.

Agnikarma is a procedure mentioned in the Ayurveda, in which a Shalaka (metallic rod) having different shaped tipped are used to burn the superficial tissues of the body at different sites depending on the disease condition of the patient. It is indicated that in the disease Gridhrasi Agnikarma is done 4 inches above or below the knee joint on the posterior aspect of the leg. The number of sitting depends upon the chronicity and severity of the disease(8). Thickness of Agnikarma Shalaka plays an important role in the procedure. A thick Shalaka gets heated well and does not cool easily and helps for the desirable effect. Thick Lauha Shalaka is used to maintain the constant temperature to produce Samyaka Dagdha Vrana. Tip of Shalaka should not be more than $1 \mathrm{~mm}$ to $2 \mathrm{~mm}$ to produce the Samyaka dagdha vrana in Agnikarma chikitsa. Precaution must be taken to produce a samyak dagdha vrana only and do not hurt the deeper tissues of the body.

To compare the effect of the Agnikarma procedure with the medical management of the disease one group of the patients are treated only with Ajmodadi Vati. It contains drugs like Ajmoda, Vidanga, Sunthi etc. that have the properties like Deepana, Pachana, Ushna, Tikshna guna and Vatanulomana. As per Chakradatta, Ajmodadi Vati is indicated for diseases like Gridhrasi, Amavata and Vishwachi.

Charakacharya mentioned most of the ingredients of Ajmodadi vati in a shoolaprashamana gana and Sushrutacharya explained in Pipalyadi gana, which acts as a Deepana, Vatakaphahara Aruchi, Amarsa Pachan, Gulma and shoola ghataka.

Ajmoda is having good property of Vatanulomana. This property of Ajamoda is helpful for eliminating the vata out of the body and reducing the pain and other symptoms of the disease virtue of its properties like Tikshna, Ushna guna. Other drugs like Chitraka, Pippali, Maricha etc also help to pacify the vitiated vata.

From the above observations it has been identified that the housewives and people doing laborious work are the most affected of the disease, because they work continuously without having proper rest to the back.

From the results it was observed that the group treated with the Agnikarma has shown marked improvement in about $65 \%$ of the case and about $92 \%$ of the cases treated with Ajmodadi Vati got improved with the treatment. The combined therapy of the Agnikarma along with the Ajmodadi Vati has shown marked relief in the symptoms in $91 \%$ of the cases. Thus from the study it can be understood that the combination therapy has given good results to reduce the symptoms of the disease.

\section{Conclusion}

From the above study it can be concluded that Agnikarma is effective in the management of the disease Gridhrasi and if the same is done with the oral administration of the Ajmodadi Vati, it gives much relief to the patient. As the study is done on a small number of patients, it can be further extended to a considerable volume of the patients to understand the effect and utilize in the treatment of the disease. 


\section{References:}

1. Parveen Kumar, Michael Clark, Clinical Medicine A textbook of Medical students and doctors, $3^{\text {rd }}$ edition, 1994, London, ELBS publishers, 414-419p.

2. Atridev Gupta, Astanga Hrudaya of Vagbhata, 12th edition, 1997, Varanasi, Chaukhambha Sanskrit Bhavan, 279-280.

3. Atridev, Sushruta samhita of Sushruta, $5^{\text {th }}$ Edition, 1975, Delhi, Motilal Banarsidas publishers, 41-44p.
4. Kashinatha shastri, Caraka samhita, $1^{\text {st }}$ edition, 2001, Varanasi, Chaukhambha publishers.

5. Laxmipati Shastri, Yogaratnakar, 7'th edition, 1999, Varanasi, Chaukhambha publishers.

6. S.Shriwastava, Sharangdhar Samhita of Sharangadhara, $2^{\text {nd }}$ edition, 1998, Varanasi, Chaukhambha publishers.

7. Sudarshana Shastri, Madhav Nidana, $32^{\text {nd }}$ edition, 2002, Varanasi, Chaukhambha publishers.

8. Gupta PD, Technological innovation of Agnikarma, $1^{\text {st }}$ edition, Nagpur, 1993. 